\title{
Don't just click 'download': The case of U.S. military expenditure data
}

\section{Jurgen Brauer}

Jurgen Brauer is Emeritus Professor of Economics, Hull College of Business, Augusta University, Augusta, GA, USA, and Visiting Professor of Economics, EBA Program, Faculty of Economics, Chulalongkorn University, Bangkok, Thailand. He may best be reached at brauer.jurgen@gmail.com.

\section{Abstract}

With a view toward two purposes, the article examines measures of United States military expenditure. It first discusses what types of data would be most suitable for the analysis of the economic burden of such expenditure and it explains, second, why existing databases with U.S. (and global) military expenditure coverage have limited validity, and therefore utility, for the first purpose. The article advances the concepts of minimal and maximal augmented military expenditure measures to better capture the full economic resource burden imposed on an economy than do the presently available measures. The difference of current measures to the proposed augmented measures is not primarily one of an intercept change but mostly of a slope change. The article claims that, by fiscal year 2018, the economic burden imposed by military expenditure on the U.S. economy when using the augmented measures is about double the size of the burden as measured by all of the currently available measures. Since, to date, most empirical work on the effects of military expenditure on economies tends to rely on inappropriate measures, misleading findings may have resulted.

E xtensive theoretical and statistical literatures have developed which theorize, measure, and analyze countries' military expenditure and their economic causes and effects, if any. Among these, the literature on the relationship between military expenditure (as cause) and economic development in general and economic growth in particular (as effects) is very large, with recent reviews coming to the still hedged conclusion that most countries in most circumstances do not benefit economically from military spending, and probably suffer adverse economic consequences therefrom. ${ }^{1}$ Yet inferential statistical analysis of any hypothesized relation between military spending and economic growth depends on a number of validity concepts among which are construct validity and content validity, the notions that (1) a measure used in an empirical setup should equal, or well correspond to, its theoretical companion construct and (2) that a measure should correspond to all facets of a given construct, not a selection thereof. ${ }^{2}$

To date, in applied statistical work, the often implied construct and content of military expenditure are not equal to its measure, and it tends to be the measure that drives causal conclusions in regard to the effect of military expenditure on economic growth. Needless to say, this harbors the possibility of unreliable findings having been reported in the literature. The reason for the mismatch between theory and empirics is straightforward: In most cases, the data used in empirical studies rely on countries' select budgetary rather than full (or at least, fuller) economic resource use measures of military expenditure. It is one thing to use readily downloadable military expenditure data compiled to give users a sense of countries' current-year military activity (often taken as a proxy for military capacity or capability) or to provide a sense of current-year government budget allocations. It is another matter entirely to use the same readily downloadable data in studies regarding economic questions. Indeed, even studies restricted to investigating budgetary trade-offs between military and nonmilitary budget items such as health, education, housing, and welfare cannot unquestionably rely on budget data alone as government line items in agency budgets (the departments of health, education, housing, and so on, as well as national defense) first need to be assigned to larger functional rubrics lest some portion of military expenditure, for example, be spread across various agencies and therefore not be captured within a single agency budget such as that of a Ministry of Defense (MOD). In the United States, for instance, military-nuclear activities are budgeted under the agency of the Department of Energy (DOE) but, clearly, contribute to the larger national defense function.

Most national government budgets are constructed on a cash basis for administrative purposes. ${ }^{3}$ It is important to acknowledge that, as such, they have their valid uses. However, even if agency budgets are mapped onto larger government functions to which various agencies may contribute, such as national defense, and even if relevant aspects of various agency budgets are added up toward an overarching national defense functional category, they still may 
not fully capture all economic resources devoted to a state's defense function. Further adjustments may be necessary. In the United States, the National Income and Product Accounts (NIPA) produced by the Department of Commerce's Bureau of Economic Analysis (BEA) can be viewed as an exercise in that direction. All federal receipts and expenditures are subject to adjustments, including coverage and timing adjustments (see the Appendix) and then are translated into NIPA categories. They are "measured on a national income and product account (NIPA) basis" (Ludwick and Brankin, 2018, p. 18). To emphasize the purpose of the translation, the BEA authors write that " $[\mathrm{u}] \mathrm{nlike}$ the federal budget, which is a financial plan of the government, the NIPA federal sector estimates are designed to facilitate macroeconomic analyses of the effects of federal government activity on economic activity" (Ludwick and Brankin, 2018, p. 18).

It is this national income accounting framework that is relevant for economic analysis of defense or military activity (rather than for, say, current-year force capacity or forcecapability analysis). As will be shown, however, even the BEA's NIPA numbers violate content validity as they still capture only a selection of the economic resources devoted to the U.S. military sector so that further adjustments to the data are required before their use in empirical economic analysis.

This article extends (and corrects) the descriptive portion of Brauer (2007), expanding his Augmented NIPA-based measure of United States military expenditure by an additional 38 years-from the 1962-2002 period $(n=41)$ to the 1940-2018 period ( $n=79)$ - and compares it to six measures such as those of WMEAT, NATO, and SIPRI, which are among the most frequently used military expenditure data employed by researchers and global news media. ${ }^{4}$ The six customary measures are discussed in the next section, along with an indication of why they are selective in their coverage of military expenditure. The section thereafter discusses two enhanced measures. First, the NIPA measure essentially converts the federal budget from a cash to an accrual basis and, it turns out, is little different from the customary measures, largely because it, too, is selective in its coverage. In contrast, an Augmented NIPA-based measure of military expenditure is less selective, and the resulting numeric difference is very large indeed. The article concludes that empirical economists might wish to rethink their reliance on found military expenditure data alone and construct their own country-specific series of economically relevant military expenditure data.

Six customary measures of U.S. military expenditure For the United States, there exists a single, ultimate source for military expenditure data. That is the Budget of the United
The article discusses construct and content validity of measures of U.S. military expenditure. It finds that all of the currently available measures fall short of capturing the opportunity cost of diverting resources from an economy's civilian to its military sector. The article then constructs minimal and maximal augmented measures of U.S. military expenditure and finds that for fiscal year 2018, the augmented measures are about double the size of measures currently used by researchers and global news media outlets. It is likely that scholars, journalists, government officials, and policymakers do not fully appreciate the size of the opportunity cost of U.S. military expenditure.

States Government or, more precisely, the Historical Tables, a document supplementary to the fiscal year budget request made each year by the governing administration to Congress and issued annually by the Office of Management and Budget (OMB) within the president's office. In contrast to fiscal year budget requests and subsequent congressional budget authorizations and appropriations (which are fiscal year spending limits and subsequent to which supplementary appropriations may be made), the Historical Tables (HT) capture the actual outlays incurred in prior fiscal years. The outlays data presently are compiled in two ways, important to understand the distinction between agency-based data and economic resource use data. This section discusses details of the first of these. The second compilation and a new, third, one are discussed in the follow-on section.

\section{Compilation No. 1}

The first type of compilation - of the type that WMEAT, NATO, and SIPRI construct, and therefore the one that most researchers and news media looking for cross-national military expenditure data rely upon - picks a selection of U.S. federal government agency budget line items that, for example, fit NATO's military expenditure definition. ${ }^{5}$ So do WMEAT and SIPRI. For SIPRI, at least, the intention is to measure currentyear military activity not as a proxy for military output or strength but as an input, "an easily identifiable measure of the scale of resources absorbed by the military," and this may or may not equate to its full opportunity cost. ${ }^{6}$

As it turns out, WMEAT and NATO data are virtually identical for 1989-2016 (the latest available, comparable data), as were NATO and SIPRI data for 1949-2005. As from 2006, however, NATO (and therefore WMEAT) data exceed SIPRI's. This may be due to NATO's recent inclusion of budget items relating to U.S. intelligence services, which SIPRI excludes, although NATO's definition does not refer to intelligence services directly. ${ }^{7}$ Since 2006, the NATO-to-SIPRI overage has averaged 8 percent, ranging from a high of 17.5 
percent in FY2008 to a low of 3.2 percent in FY2010. Even at 8 percent, the difference nonetheless is small relative to the economically more relevant Augmented NIPA-based account, as shown in the next section.

Still other U.S. military expenditure data sources include the World Bank, the International Monetary Fund (IMF), and the United Nations Office for Disarmament Affairs (UNODA). ${ }^{8}$ The World Bank reports military expenditure data under license from, and therefore equals, SIPRI's. The IMF also relies on SIPRI (e.g., IMF, 2019). UNODA's data are not used by research economists, for multiple reasons. The time periods covered can be short (for the United States only as of FY2002) and the data are at times inconsistent and often miss many years. UNODA also reports data with a greater time-lag than do the other sources. Its numbers stem from states' self-submitted data, based on states' agency budgets adjusted to fit UNODA's rather than NATO's more expansive definition of military expenditure. ${ }^{9}$ Indeed, NATO's numbers generally exceed UNODA's, in one instance by over USD106 billion (in FY2008). State responses to UNODA data requests are voluntary, and the number of respondents has dropped from more than 70 states in the 2000 s to about half that number in 2018 .

In sum, until 2005 the three major international data sources researchers and news media have used to gauge U.S. military expenditure data-WMEAT, NATO, and SIPRI - all reported almost identical figures. Since then WMEAT and NATO remain almost identical but, as noted, NATO/WMEAT and SIPRI data have begun to diverge (on average by USD47 billion/year; or USD35 billion/year when excluding the untypically large divergences of FY2008 and FY2009).

As indicated, the Historical Tables distinguish outlays by government function from outlays by the agencies that carry out one or more functions. For example, while functional budget line item 051 includes outlays only of the Department of Defense (DOD) agency, the budget of the Department of Energy (DOE), another agency, includes some defense-related functions, specifically military-atomic energy (functional budget line item 053). Thus, the overall National Defense Outlays (NDO) functional budget line item 050 is broader than that of the DOD agency alone and therefore exceeds the DODrelated functional line item 051 . Compared even to this more comprehensive functional budget line item, NATO adds an average of USD14 billion/year (averaged over 1949-2018). As with the case of SIPRI, this average annual "add-on" increased drastically with FY2006, rising to an average of USD55 billion/year. Compilation No. 1 in Table 1 shows comparative data for some recent years. Consider the numbers for FY2017 for example. Historical Tables functional budget line item 051 (the DOD agency budget) amounts to USD527.0 billion. Summing line items 051, 052, 053, and 054 (defense-relevant items from DOD, DOE, and some others) results in functional line item 050 (National Defense Outlays) of USD554.6 billion (the DOD+ line in the table). SIPRI's number adds another USD10.3 billion to reach a total of USD564.9 billion. NATO ups this to USD595.6 billion. $^{10}$

\section{NIPA and Augmented NIPA data}

Compilation No. 2

The second compilation of Historical Tables data comes from the National Income and Product Accounts (NIPA), produced by the Bureau of Economic Analysis (BEA) in the U.S. Department of Commerce (DOC). ${ }^{11}$ NIPA's NDCE number, that is, National Defense Consumption Expenditure, which for FY2017 comes in at USD555.8 billion, includes a depreciation charge due to prior years' National Defense Gross Investment Expenditure (NDGIE). Adding the FY2017 gross investment of USD133.3 billion brings the combined National Defense Consumption and Gross Investment Expenditure (NDCGIE) to 
a total of FY2017 USD689.1 billion.

As mentioned, the NIPA's are constructed with a national income accounting purpose in mind, that is, ultimately the production of a figure for Gross Domestic Product (GDP). For current-year GDP production - the monetary value of all goods and services produced in a country in a year's time-it is fine to include both investment in new defense-related equipment, structures, and other assets as well a depreciation charge to account for the use (or consumption) of past such investments in the current year's production of defense services. But as a measure of current-year military-related readiness activity, this would amount to double-counting - as investment is geared at future readiness while past investment is captured through the depreciation charge-and thus cannot stand. Instead, the relevant number to track is just the defense consumption item (NDCE), shown as the bold-font, red-colored, dashed line in Figure $1 .^{12}$ As can be seen, NIPA's NDCE numbers lie well within the cluster of the six customary Compilation 1 lines that show the two functional Historical Tables measures (budget line items 050 and 051), SIPRI, NATO, WMEAT, and UNODA for all years since FY1940. (All numbers are inflation-adjusted using the GDP implicit deflator measure, with 2012 serving as the base year.)

Yet, as is argued shortly, by FY2018 all Compilation 1 and 2 lines fall well short, by over a half trillion dollars, of a fuller economic accounting of U.S. military expenditure. This is the Augmented NIPA-based measure (Table 1, Compilation 3). If the red-colored, dashed NDCE line in Figure 1 has, in effect, no effect, the same cannot be said of the eighth line, the boldfont, teal-colored, dashed line that runs atop all others in Figure 1. Since 1940, this Augmented NIPA line rises with a noticeably steeper slope than do the others and might well affect regression coefficients in model estimations of the effect of military expenditure on economic growth. This is the point that, I believe, applied research economists need to grasp. What accounts for this massive (and rising, over time) increase?

\section{Compilation No. 3}

To construct an Augmented NIPA-based measure of U.S. military expenditure, a third data compilation is necessary as the BEA's translation of U.S. budget numbers into the national income and product accounting framework still leaves out three crucial aspects. First, BEA's treatment of homeland security expenditure in the NIPA; second, its treatment of military legacy costs of which, third, the quantitatively most important one concerns net interest payments incurred on federal debt obligations. The detailed discussion that follows constructs what might be called a Maximal Augmented NIPA measure of

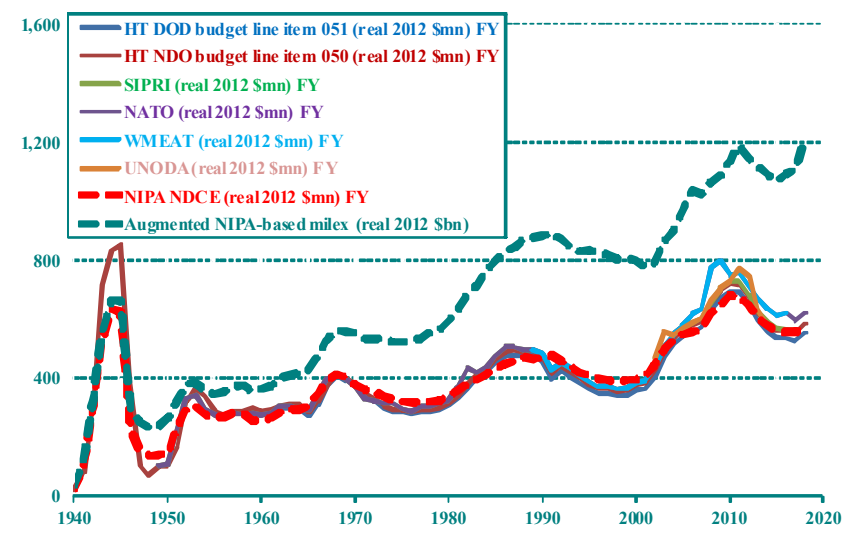

Figure 1: Measures of United States military expenditure (real 2012 millions of dollars). Sources: See text.

military expenditure. Thus, in the subsequent discussion and conclusion, a suggestion also is made on how one might construct a corresponding Minimal Augmented NIPA measure.

\section{Homeland security}

To understand treatment of homeland security data, first go back to the U.S. budget data (Historical Tables). The U.S. Department of Homeland Security (DHS) was established in 2002, following the 11 September 2001 terror attacks on the country. In terms of the U.S. budget documents, the Historical Tables data reclassify all pre-2002 spending so as to create a "phantom" DHS agency line item that starts in $1962 .{ }^{13}$ According to the DHS website, the department was constructed by compiling some " 22 different federal departments and agencies into a unified, integrated Cabinet agency."14 Thus, going backward, the budget items for the departments and agencies that formerly carried out DHS-type activities now carried out by DHS were reduced in order to establish the DHS "phantom" agency line item for 1962-2001. Thereafter, of course, the phantom agency became an agency in its own right. Unfortunately, from the budget documents alone one cannot determined just how the DHS agency budget — phantom and otherwise - in turn is reclassified into function budgets as correspondence tables are not made public as part of the Historical Tables document. As mentioned, functional budget line item 050 is the whole of National Defense Outlays (NDO). The next super-category line item is 150 (International Affairs), followed by 250 (General Science, Space, and Technology), and so on. As there is no corresponding supercategory functional budget line for homeland security, the implication is that DHS spending is distributed across all the other government functions but in an unknown way. ${ }^{15}$ Even without a correspondence table, one can in some cases deduce the mapping of agency-to-function items, either fully or 
partially. For instance, there is a super-category line item 700 (Veterans Benefits and Services) with a FY2018 function budget of USD85,535 million as opposed to USD178,513 million for the Department of Veterans Affairs (DVA) agency, which leaves DVA outlays of USD92,978 million (about 52 percent) reclassified to other, unknown, budget functions which may or may not include the defense function. The DOD-Military Programs agency budget in FY2018 was USD600,714 million, and for an agency referred to as Other Defense Civil Programs it was another USD55,367 million. The DOD agency budget shows up unchanged in the functional assignment (line item 051) but of the Other Defense Civil Programs only USD9,528 million carry over to function budget line item 054, called "Defense-related activities".

From Ludwick and Brankin (2018), confirmed by personal correspondence with BEA economists, neither BEA's NIPA NDCGIE, nor its consumption and gross investment components, include any homeland security agency or function outlays and, therefore, the whole of the DHS agency budget could be added to NIPA's NDCGIE figure but it is not known which DHS portion should be added to NDCE and which to NDGIE. For the illustrative purposes of this article, and at least as an initial step, the whole DHS agency budget has been added to NIPA NDCE. Including the entire DHS budget in the Augmented NIPA surely overstates things. DHS does support military activities such as intelligence gathering, and possibly the U.S. Coast Guard, but not all DHS spending will be military related. But without a detailed, line-by-line DHS budget breakdown, one cannot know which parts to count nor know which parts are consumption and which are gross investment. ${ }^{16}$ Of course, one can simulate and include just half or even none of DHS in the Augmented NIPA-based numbers and this is briefly discussed in the concluding section.

\section{Legacy costs}

As is clear by now, measuring military expenditure is not a straightforward exercise. Another problem area concerns the legacy cost of past military activity. Note, for instance, the treatment of retirement pensions. SIPRI includes pension contributions to former military employees of ministries of defense (MOD) - the Department of Defense (DOD) in the case of the United States-regardless of whether pension contributions are budgeted under the MOD rubric or elsewhere. ${ }^{17}$ In contrast, NATO claims that it includes both the in-service pension contributions as well as the post-service actual pensions of MODs' military and civilian personnel (NATO Press Release, 14 March 2019, pp. 14-15). But if this is so, NATO and SIPRI numbers should not have been equal (until 2005). SIPRI defines military expenditure on its website to include expenditure on "personnel, including: a. salaries of military and civil personnel; b. retirement pensions of military personnel, and; c. social services for personnel" (quoted from SIPRI's military expenditure data website) but clarifies in an email that "retirement pensions of military personnel" refers to the employer's contribution to the employees' retirement fund, not to the pensions themselves. In any case, SIPRI excludes retirement fund contributions to MODs' civilian personnel, whereas NATO claims to include that.

Either way, if SIPRI aims to exclude all legacy $\operatorname{costs}^{18}$ and if NATO includes one type of legacy cost (pensions) but not others in their respective military expenditure compilations, the question arises of why to exclude any or all legacy costs in the first place if one wants to use military expenditure data to study its economic effects on an economy? If one does include pensions, as NATO claims, why not also include coverage of veterans' continuing health care and other needs? This is inconsistent: If pensions are included as current expenditure due to prior military activities, one cannot exclude other current expenditure on prior military activities such as veterans' health care coverage and other benefits they may receive. Similarly, BEA's NIPA numbers include pensions and pension contributions (see Ludwick and Branklin, 2018, Table 4) but exclude the whole of the budget of the Department of Veterans Affairs (DVA) from the computation of national defense consumption and gross investment expenditure (NDCGIE).

The crux of the matter regards content validity: Does the content of a measure match the theoretical construct one hopes to capture with that measure? To be valid, the measure cannot be selective in its coverage. In the case of military expenditure, one cannot include some legacy costs (pensions) and leave out others (health care and other non-pension services). Either exclude both or include both. For the purposes of this article, the whole of the DVA agency budget has been added to NIPA's NDCE fiscal year numbers on the economic argument that one must look at the allocation of current-year economic resources regardless of when a future resource-use obligation may have been incurred. (As noted, for FY2018 the supercategory function budget for Veterans Affairs is but half of the DVA agency budget. Later on I will comment on the size of the "add-in" when producing Augmented NIPA numbers.) Thus, if hiring a soldier in the year 1970 includes or implies a contractual promise to provide pension and health care benefits in the year 2018, then the actual 2018 spending fulfills the promise made and is to be counted as military expenditure in terms of the use of total economic resources available to government in 2018. If, in contrast, one were interested in current-year force capacity or capability - which, one ventures, 
is what most defense and media analysts are interested in - then it would be proper to exclude all legacy-related payments, not just health care but also all pensions. In a word, when downloading numbers off websites, one must consider the purpose of one's analytic interest and must possibly reconstruct any downloaded numbers so that they fit that purpose.

\section{Net debt (issued and redeemed) and net interest paid} A third adjustment to NIPA's NDCGIE numbers concerns the treatment of net debt and net interest paid. Net debt issued finances current-year government activity, including militaryrelated activity. For instance, by the end of FY2018 that year's federal budget deficit amounted to (nominal) USD779 billion, covering the shortfall between receipts of USD3,329 billion and outlays of USD4,108 billion. The U.S. Treasury's Monthly Treasury Statement details how this shortfall is financed. ${ }^{19}$ These are complex and offset, for example, total borrowing needs against intra-governmental borrowing and changes in government cash-on-hand. The upshot is that FY2018 total net borrowing from the public amounted to USD1,084,458,000 ( $\sim$ 1 trillion). With the national defense budget function constituting USD665 billion or 16.2 percent of the USD4,108 billion in outlays that year, one might argue, incorrectly I think, that 16.2 percent of the net borrowing from the public (USD176 billion) is attributable to the defense function, a diversion of national resource flows away from the private sector or nonmilitary government purposes.

The issue to consider here is whether to count debt as an opportunity cost. Does the financing of government activity matter or only its claim on actual real resources, as NIPA suggests? If, say, USD100 of national defense outlays (NDO) were financed not by net borrowing from the public but by increases in taxation or a corresponding reduction in nonmilitary government outlays, what would change? To illustrate, consider two scenarios in one of which the USD100 is wholly financed by taxes and, in the other, wholly by new debt. In either case, we would count NDO of USD100 - since that is the outlay, which NIPA converts to an accrual basisso that the opportunity cost is no less when financed by taxes than when financed by debt. The future redemption of the debt amounts to a deferred tax, and the question would be when to count the tax burden, in the year debt was issued or the year, or years, during which the debt was redeemed (the principal repaid). None of this reasoning invalidates the construction of the NIPAs, given BEA's GDP objective. (In practice, much of the net borrowing is needed to roll over debt — redeem old debt by issuing new debt - and to pay interest obligations on past debt raised.) At issue is not the debt, nor its redemption, but the additional cost that the debt imposes, the interest on debt.

The U.S. president's own budget proposal, forwarded to Congress for debate, acknowledges the overwhelming contribution of military expenditure to the nation's accumulated debt and, hence, to the payment of interest on that debt (e.g., Historical Tables, FY2020, pp. 5, 6, 7, 8, etc., as well as in any number of Historical Tables documents for preceding fiscal years). Yet NIPA does not allocate a militaryassignable portion of the interest paid to the NDCGIE category (nor does any other data source). BEA's argument is the following: "Government interest payments, although included elsewhere in the NIPA's, are not considered to be a payment for factor services; they, therefore, are not recorded in the government production account" (BEA, 1988, p. 4). And elsewhere: "Estimates of real spending by function refer to real government consumption expenditures and gross investment by function, which appear in NIPA table family 3.15 and which constitute a portion of GDP. These estimates exclude other types of government expenditures - such as social benefit payments, grants-in-aid, interest payments, and subsidies - that do not directly contribute to GDP" (BEA, 2005, p. IV-4).

Interest paid on debt obligations is not a current-year military production or service activity, true. Yet such payment does absorb current-year economic resources, the opportunity cost of which lies in foregone nonmilitary uses, private or public. Moreover, the interest has to be paid both on the defense consumption and on the defense gross investment expenditure. One might argue that interest payment recipients recycle the receipts into private sector consumption or gross investment, thus channeling the monies back onto the nonmilitary expenditure side of GDP (at home or overseas, for the portion of debt held outside the U.S.). True again, but had debt investors not lent funds to finance government military activity in the first place, they would have invested elsewhere and also recycled any interest received. At any point in time, funding the military side of GDP makes the nonmilitary side smaller than otherwise it might have been. It is not just adherents to the Austrian school of economics who appreciate that military-related debt and interest payments can help finance a skew in the economy's productive structure. ${ }^{20}$

For the purposes of this article, therefore, the portion of federal net interest payments on federal debt assignable to the total (consumption and gross investment) military function of government has been added to NIPA's NDCGIE numbers.

\section{The Augmented NIPA numbers}

To illustrate the construction of Augmented NIPA numbers for FY2018, the latest available at the time of writing, consider the following computations (Table 2). Ignoring rounding errors, 
Table 2: Augmented NIPA (in real 2012 billions of dollars, rounded, FY2018)

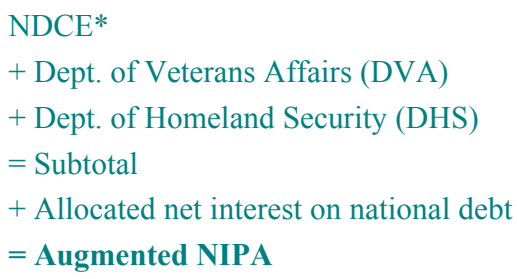

FGCGIE*

NDCGIE/DHS/DVA share in FDCGIE (USD942.0 bn / USD1,195.7 bn)

Sources: See text. Note: NDCE, NDCGIE and FGCGIE are, respectively, national defense consumption expenditure, national defense consumption and gross investment expenditure and federal government consumption and gross investment expenditure.

the Augmented NIPA of USD1,202.8.5 billion (that is, 1.2 trillion dollars) is the sum of (1) NIPA's NDCE [USD577.4 billion], (2) the Department of Veterans Affairs' budget [USD160.2 billion], and (3) the Department of Homeland Security's budget [USD76.3 billion]-for a subtotal of USD813.9 billion - plus (4) interest payments assigned to the country's total military function [USD389.0 billion]. The interest payments are computed as follows: NIPA records federal government net interest payments as USD493. 7 billion. It also records Federal Government Consumption and Gross Investment Expenditure (FGCGIE) — defense and nondefense combined - as USD1,195.7 billion, the NDCGIE defense share (USD705.6 billion), plus DVA (USD160.2 billion) and DHS (USD76.3 billion), of which is 78.8 percent. That percentage applied to the net interest payments equals USD389.0 billion ( $0.788 \times 493.7)$. One can repeat the exercise back to FY1940 and plot the resulting line, the bold teal-colored, dashed line in Figure 1. Thus constructed, the augmented U.S. military expenditure measure has grown over time far more than have the other measures as the underlying accumulated debt and hence interest attributable to the total military function (NDCGIE+DHS+DVA) have grown.

For the United States, the global news media frequently report a military burden-the percentage of military expenditure (milex) to gross domestic product (GDP)—such as
3.1 percent for FY 2018, if military expenditure is taken to be the budget's functional National Defense Outlays (NDO) line item 050. (In real 2012 dollars, that is USD582.7 billion divided into USD18,571.3 billion.) Even though SIPRI's and NATO's military expenditure data are larger than the NDO figure, this rarely moves even the first decimal in the military burden number as the U.S.'s underlying GDP is so large. ${ }^{21}$ In contrast, when using the Augmented NIPA measure the military burden rises from 3.1 to 6.5 percent of the nation's GDP, more than double the 3.1 number researchers and the news media tend to use. Put differently, in terms of economic resource use, for FY2018 the burden is not three cents on the dollar, but six-and-a-half cents on the dollar.

\section{Discussion and conclusion}

Whichever data one applies to statistically test a hypothesis developed from theory, it should at least meet the criteria of construct and content validity. As constructed in this article, the Augmented NIPA data probably overstate the economic resource use for military or defense purposes - the data may be thought of as Maximal Augmented NIPA-but they possibly do capture the vast proportion of such spending. For example, if the DVA and DHS agency budgets contribute even half as much as assumed here, then the overstatement would be less than 10 percent, and the resulting military burden 5.9 instead of 6.5 percent - still a substantial increase over the 3.1 number generally reported in the news media. This is because the annual net interest paid on national debt due to the total national defense effort is so large as to overwhelm the addition or subtraction of a few other items. Indeed, given the national debt loads carried by central governments around the world, it should be relatively straightforward to make progress toward a Minimal Augmented Milex measure by adding to national defense budgets the annual net interest obligation due to national defense budgets' share in annual central governments' budget deficits.

I reach three conclusions. First, research economists would do well to refocus on a "Mind Your Purpose, Mind Your Data" stance. If the research purpose at hand concerns current-year military capacity or capability, then military legacy costs, including net interest on national debt, are irrelevant, of course. But if the purpose concerns opportunity costs, then something akin to the Augmented NIPA data should be used (and developed for countries other than the United States, many of which carry far larger interest burdens, relative to GDP, than does the United States). Put differently, “don't just click on the 'download data' button'.

A second, related, conclusion concerns the need to deposit new data assemblies, along with documentation, to a reliable 
and credible institutional home for eventual panel dataset collation across time and countries.

Third, inasmuch as global news media help generate public understanding and sentiment regarding countries' military expenditure they, too, need to heed the main lesson of this article as it is quite possible that whether the United States expends "merely 3" or "about 6" percent of the value of its entire annual economic production on its military efforts alone could make a political and/or electoral difference.

\section{Notes}

The author gratefully acknowledges the receipt of very helpful comments from J. Paul Dunne, Christos Kollias, Eftychia Nikolaidou, Nan Tian, and two anonymous reviewers. All remaining errors and omissions are the author's.

1. Put differently, the case for military expenditure is best not made on economic grounds but on its own merits. See, e.g., Dunne and Tian (2016), Brauer, Dunne, and Tian (2019), Smith (2019), and the literatures cited therein.

2. In economics much data is collected using Keynesian constructs but not necessarily used in that way, so problems of construct validity are common. There is also an issue of temporal validity, measuring the same thing over time (Dunne, 1991). Additionally, there are problems of content validity. Gross domestic product (GPD), for instance, excludes nontraded production such as (most) household-related work and thus measures production selectively.

3. Some countries, such as Australia, Sweden, and the U.K., have switched to an accrual basis but this will not change the larger point the article makes as even on an accrual basis some types of military-related expenses are left out of the accounting. The U.S. also has an accrual measure, rarely used in practice, but fundamental to the discussion in this article.

4. Respectively, the World Military Expenditures and Arms Transfers publication, issued annually by the U.S. Department of State (see www.state.gov/t/avc/rls/rpt/wmeat/), the North Atlantic Treaty Organization (www.nato.int), and the Stockholm International Peace Research Institute (www.sipri.org). Data downloads are free of charge.

5. For NATO's lengthy definition, see p. 14 of its latest defense expenditure-related press release of 14 March 2019 at www.nato.int/cps/en/natohq/news 164482.htm?selectedLoc ale=en. Note that, despite its length, NATO's published definition of military expenditure remains opaque. Unhappily, NATO's press releases are not issued as standard downloadable spreadsheet files but as PDF files with uneven dating (sometimes in January, sometimes in March, sometimes in July, and so on) and with inconsistent coverage of time periods.
6. SIPRI is explicit about its intention: "The main purpose of the data on military expenditure is to provide an easily identifiable measure of the scale of resources absorbed by the military. Military expenditure is an input measure, which is not directly related to the 'output' of military activities, such as military capability or military security. Long-term trends in military expenditure and sudden changes in trend may be signs of a change in military output, but interpretations of this type should be made with caution." See Stålenheim and Sköns (2008, p. 242). For example, if a U.S. soldier is, say, twice as "productive" as a non-U.S. soldier but costs thrice as much, then mere monetary accounting as an input measure does not, of course, capture comparative military capacity or strength as output measures.

7. Personal communication from Dr. Nan Tian, Arms and Military Expenditure Program, Stockholm International Peace Research Institute (1 April 2019).

8. World Bank: See https://data.worldbank.org/indicator/MS. MIL.XPND.CD?view=chart. UNODA: See http://www.un-arm .org/Milex/home.aspx [accessed 11 April 2019]. An additional source, not widely used among researchers but gaining prominence in the news media, is the Sydney-based Institute for Economics and Peace (IEP) which publishes an annual Global Peace Index (GPI). The GPI includes a measure of military expenditure as a percentage of GDP, which is taken from the International Institute for Strategic Studies' annual Military Balance publication. Researchers tend not to use Military Balance data as its data sourcing remains opaque (and is not available free of charge either).

9. The U.S. data submission for FY2014 to UNODA states that it includes the following: "The military expenditures (actual outlays) are of the individual military departments (Army, Navy, Air Force) and the defense agencies within the Department of Defense, as well as the Department of Energy (for defense nuclear programs) and the Department of Homeland Security (for defense-related activities)."

10. As of 11 April 2019, WMEAT and UNODA numbers were not yet available for FY2017. As discussed, they tend equal or lie below NATO's.

11. NIPA's nominal US dollar numbers are available online at BEA's interactive data tables site, https://apps.bea.gov/iTable/ index_nipa.cfm. Click "Begin using the data ..." and then click on Section 3 (Government Current Receipts and Expenditures). Then scroll down to and click on Table 3.9.5. (Government Consumption Expenditures and Gross Investment). At this point, the table can be modified to select all available years. When finally displayed, scroll down to the table's Line 17 [accessed 11 April 2019] to see the figures for National Defense Consumption and Gross Investment Expenditures (NDCGIE).

12. Unlike federal budget outlays, which are recorded on a cash basis, NIPA expenditures are recorded on an accrual basis. In the end, we are talking about the same aircraft, missiles, ships, and so on, just differently accounted for. The 
dollar difference between the budget's NDO and NIPA's NDCE numbers is relatively minor.

13. See Historical Tables, FY2020, Table 4.1 Outlays by Agency, 1962-2024, starting on p. 74 of the document.

14. See https://www.dhs.gov/history [accessed 12 April 2019].

15. A 12 April 2019 request to the president's Office of Management and Budget (OMB) to supply a correspondence map or table went unanswered.

16. Similarly, portions of the DOD budget should be classified as nondefense outlays. The United States Army Corps of Engineers, for instance, is part of the DOD budget yet almost all the funding ( USD5 billion in 2017) is not related to military activities and thus would need to be deducted from the DOD budget. Presumably NIPA does this, but detailed correspondence tables to translate the DOD budget into NIPA categories are not (made) available.

17. To be clear, what is included is the in-service monthly fringe benefit contribution (the pay-in) to service personnel's future, post-service pension claims, not the post-service pension itself. The legacy cost is excluded.

18. SIPRI is explicit in its exclusion of non-pension benefits: “... current expenditures on previous military activities, such as veterans' benefits, demobilization, conversion and weapon destruction are excluded" (https://www.sipri.org/ databases/milex/sources-and-methods\#definition-of-militaryexpenditure [accessed 11 March 2019]).

19. https:/www.fiscal.treasury.gov/reports-statements/mts/.

20. See, e.g., Kjar and Anderson (2010) for an Austrian School view. In contrast, Anderton and Carter (2019, pp. 148-149) for example discusses military-nonmilitary resource diversion within the context of the neoclassical Edgeworth box.

21. For FY2017, the latest available, SIPRI reports a military burden of 3.1 percent (SIPRI Yearbook, 2018, p. 158), which is the same 3.1 percent military burden number as computed off budget line item 050 (National Defense Outlays).

\section{References}

Anderton, C.H., and J.R. Carter. 2019. Principles of Conflict Economics. 2nd ed. New York: Cambridge University Press. https://doi.org/10.1017/9781316875506

[BEA] 1988. “Government Transactions.” Methodology Paper Series MP-5. U.S. National Income and Product Accounts, Bureau of Economic Analysis, U.S. Department of Commerce. Washington, D.C.: Government Printing Office. Available at http: //www.bea.gov/bea/ARTICLES/ NATIONAL/NIPA/Methpap/methpap5.pdf [accessed 12 April 2019].

[BEA] 2005. “Government Transactions.” Methodology Paper Series MP-5. U.S. National Income and Product Accounts, Bureau of Economic Analysis, U.S. Department of Commerce. Washington, D.C.: Government Printing Office. Available at http: //www.bea.gov/bea/mp5.pdf [accessed 12 April 2019].

Brauer, J. 2007. "Data, Models, Coefficients: The Case of United States Military Expenditures." Conflict Management and Peace Science. Vol. 24, No. 1, pp. 55-64. https://doi.org/10.1080/07388940601102845

Brauer, J., J.P. Dunne, and N. Tian. 2019. "Towards Demilitarisation? The Military Expenditure-Development Nexus Revisited," pp. 90-117 in Ron Matthews, ed. The Political Economy of Defense. Cambridge, UK: Cambridge University Press. https://doi.org/10.1017/9781108348058.005

Dunne, J.P. 1991. Quantitative Marxism. London: Pluto Press. Dunne, J.P., and N. Tian. 2016. "Military Expenditure and Economic Growth, 1960-2014." The Economics of Peace and Security Journal. Vol. 11, No. 2, pp. 50-56. https://doi.org/10.15355/epsj.11.2.50

[IMF] International Monetary Fund. 2019. "Regional Economic Outlook. Sub-Saharan Africa: Recovery Amid Elevated Uncertainty." April. IMF: Washington, D.C.

Kjar, S.A., and W.L. Anderson. 2010. "War and the Austrian School: Applying the Economics of the Founders." The Economics of Peace and Security Journal. Vol. 5, No. 1, pp. 6-11. https://doi.org/10.15355/epsj.5.1.6

Ludwick, M., and B. Brankin. 2018. "NIPA Translation of the Fiscal Year 2019 Federal Budget." Survey of Current Business. Vol. 98, No. 3, unpaginated. Available at https://apps.bea.gov/scb/2018/03-march/pdf/0318-nipa-tr anslation-of-the-fiscal-year-2019-federal-budget.pdf.

P. Stålenheim, and E. Sköns. 2008. "Appendix 5C. Sources and Methods for Military Expenditure Data." SIPRI Yearbook 2008. Oxford, UK: Oxford University Press.

Smith, R.P. 2019. "Military Expenditure and Growth," pp. 73-89 in Ron Matthews, ed. The Political Economy of Defense. Cambridge, UK: Cambridge University Press. https://doi.org/10.1017/9781108348058.004

\section{Appendix}

Major conceptual differences exist between national defense spending as reported in the Monthly Treasury Statement and in the United States Budget and how defense consumption expenditures and gross investment are measured in BEA's National Income and Product Accounts (NIPAs). To reconcile these differences, BEA makes certain adjustments to the raw data.

As discussed in the main text, National Defense Outlays are outlays include more than just the Department of Defense's own military outlays and include, for example, the Department of Energy's nuclear weapons programs. In addition to those sorts of adjustments, coverage adjustments are made to account for certain transactions that are included in the Budget but are excluded from the NIPAs (and vice versa). Some are additions. For example, there are imputations for the consumption of fixed capital, a depreciation-like measure included in defense consumption expenditures to reflect the contributions of fixed assets (aircraft, structures, ships, etc.) to 
current period defense production - the largest difference, in dollar terms, between the NIPAs and the Budget—as well as imputations for pensions (accrual less cash), that is, an adjustment made to reflect when pension liabilities are accrued, not when they are funded. Other adjustments concern subtractions. For example, retiree Tricare benefits (Tricare provides civilian health benefits for U.S Armed Forces military personnel, military retirees, and their dependents), which are classified as transfers to individuals in the NIPAs and, additionally, transfers to the rest of the world, which include for example Afghan and Iraq Security Forces Funds, the Syria Training and Equipment Fund, and the Commander's Emergency Response Program.

Further, NIPA makes several timing adjustments to account for transactions that are recorded on a cash-basis in the Budget but are recorded on an accrual-basis in the NIPAs. These include compensation timing (e.g., payday adjustments if the first day of the month falls on weekend or holiday and paychecks are issued the previous work day and Medicare-eligible retiree health fund adjustments, an annual "lump sum" payment for a component of compensation that is spread out across the year in the NIPAs) and procurement timing (e.g., DOD disbursements occurring during quarters before and after the delivery of the weapon system, not just during the quarter in which it is delivered and timing adjustments made to reconcile NIPAs delivery approach to the disbursements approach used in the Monthly Treasury Statement).

See Ludwick and Brankin (2018) for further discussion and literature. 